"طريقة مقترحة لتعليم كتابة الإنشاء الوصفي لطلبة المرحلة الأولى في كلية التربية الرياضية بجامعة الموصل"

\author{
بكلوريوس آداب / ترجمة \\ مدرس مساعد \\ مفاز خليل حمودي \\ شذى حازم سعد الله
}

المكتبة المركزية/جامعة الموصل

كلية التربية الرياضية/جامعة الموصل

جامعة الموصل / كلية التربية الرياضية

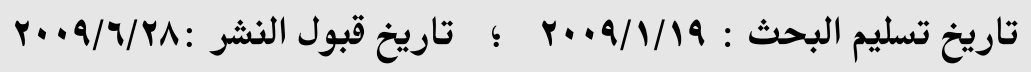

\title{
الملخص
}

يعرض هذا البحث الصعوبات التي تواجه طلاب المرحلة الأولى في كلية التربية الرياضية أثناء كتاباتهم للإنشاء، إذ لاحظنا أنهم لا يستطيعون التعبير في كتاباتهم

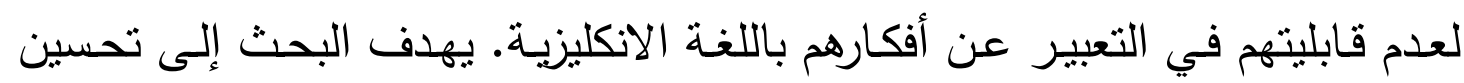
قابليتهم مـن اجل السيطرة على المهارات الأساسية لكتابـة إنشاء جيد، ولتجهيزهم

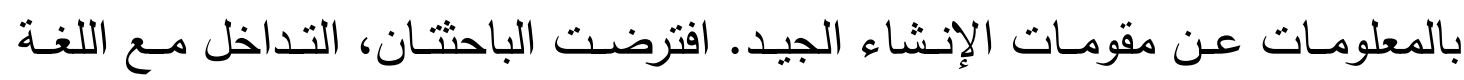
العربيـة هـي الـصفة المميـزة في أداء الطلبـة، حيـ كانـت النتـائج الأوليـة سـلبية.

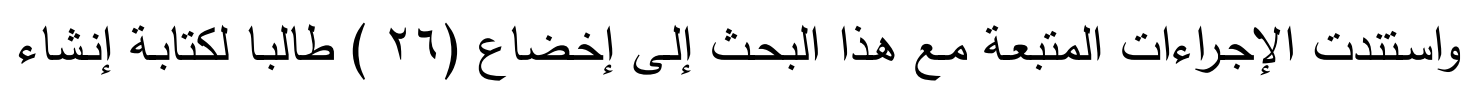

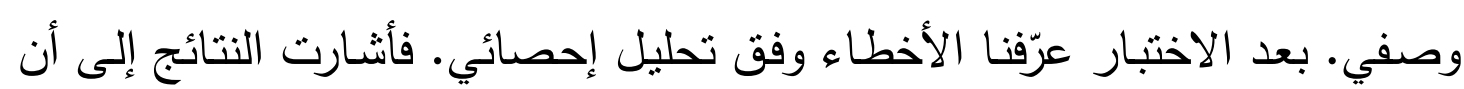
أعلى نسبة للأخطاء تمثلت في مهارات الكتابة تلتها الأخطاء في تركيب الجمل ثم الأخطاء الأسلوبية. 


\section{ABSTRACT \\ "A Suggested Method for Teaching English Descriptive Composition to First Year Students of the College of Physical Education in the University of Mosul"}

\author{
Asst. Lecturer \\ Shatha H. Sadallah \\ College of Physical Education \\ Mosul University
}

B. A. in Translation

Mafaz K. Hammoodi

Central Library

Mosul University

This investigation presents that most of the first year students of the College of Physical Education find it difficult to write a piece of composition. They can not express themselves in their writing, because they lack the ability to express their thoughts in English. The aim of this research is to improve the students' ability to handle the basic skills of writing good composition and to provide them with some knowledge of the features of a good composition. The researchers hypothesizes that the interference students of Arabic, which characterize the student performance, have a negative consequence on their final product. The procedure followed in this paper is based on asking 26 students to write descriptive compositions. After the test, the errors are identified, classified and analyzed statistically. The results indicate that the highest number of errors is in mechanics of writing, followed by sentence structure, and style.

\section{Introduction:}

In writing a good composition, the students should learn three main parts. The first one is the introduction, which contains the topic sentence carrying the main idea. The development of the topic sentence can be either partial or complete. The second part is the body of composition which embraces the main contents of the composition, and finally the conclusion. As far as the types of composition are concerned, a composition can be either descriptive, narrative, expositive, and 
argumentative. Our main concern in this study is the descriptive composition.

Most Iraqi learners of English find it difficult to write a piece of descriptive composition. To express themselves adequately, students need many things, among which are:

a- the necessary information.

b- The ability to arrange this information in a logical order.

c- The power to express it clearly, pleasantly and effectively.

Writing well does not only mean to avoid making mistakes in both grammar and spelling, but also have a good style, i.e., choosing the right topic and using the good words then joining such words in the right order.

\section{Theoretical Background:}

The word "composition" comes from a Latin word meaning "putting together". Hanks and Porter (1972: 343) define the term composition as the art of putting words and sentences together in accordance with the rules of grammar and rhetoric. The term composition is also defined as a short piece of writing done at school, in an exam...etc (Hornby, 1961: 149 and Steel, 2000: 136). Al-Nakkash (1978: 130) gives a similar definition. She states that composition is any piece of continuous written English and not merely single unrelated sentences.

Suleimani (1996: 22) defines composition as a type of activity used in developing writing skill. Rutherford (2008: 2) states that composition in a written language refers to the process and study of creating written works or pieces of literature. According to the composition theorist, Bartholomae (2008: 327), composition is the institutionally supported desire to recognize and evaluate the writing of unauthorized writers, to control writing in practice and to define it as an object of professional scrutiny.

In this research we are concerned with purely descriptive composition which is a record of observed facts (Al-Hamash, 2000: 81). 
Alexander (1965: 18) defines descriptive composition as an act of writing that is generally required to describe people, objects, or scenes. For Furnish (1996: 192) if one is trying to describe a scene, an event or a time in history, he must put the reader there by including vivid details. Description creates a dominant impression on persons, places, or things through the use of vivid details arranged so that the reader can also see or experience the thing described (Forlini, 1982: 505). Or it may be purely imaginary (Alexander, 1965: 18). Al-Hamash (2000: 81) states that descriptive composition is of various kinds. It may be quite simple, as when one describes a common object, or it may be more difficult or complex, as when one describes a well known building, person, or a piece of natural scenery.

\subsection{The Plan of Writing Composition:}

Glatthorn, Rosen (1990: 119) states that one can plan a composition by using many of the techniques used for planning paragraphs of first finding a topic then developing the topic by following three steps:

- listing details

- identifying the main points

- organizing the supporting information.

Al-Hamash (2000: 77 f) mentions essential points that must be followed in writing a composition. For him, a good composition is built gradually. It follows many steps. First, gathering sufficient material on the subject and this involves making a list of any ideas on the subject. Second, finding a way of arranging the material in some sort of logical order, and these are sorted out under sub-headings. Then, they must be collected under proper headings. These sub-headings will not be the topics of paragraphs. In the finished composition, Al-Hamash (Ibid: 77) concludes that when composition is written, one should read it very carefully, watching particularly for misused inappropriate words and for errors in spelling, word order, and punctuation. 


\subsection{The Controlling Idea and the Topic Sentence:}

A good composition must have a controlling idea and minor ones which develop the controlling idea. According to linguists the controlling idea may be encompossed in a sentence or a paragraph (Chaplen: 1970, Forlini: 1982, Suberman: 1956 among many others). The controlling idea is the central idea that is developed in a paragraph. Therefore, it is the summary of all the information contained in the paragraph.

According to Chaplen (1970: 9), if the controlling idea is contained in one sentence, that sentence is called the topic sentence because it contains the idea or topic that is developed and explained in the rest of the paragraph. The topic sentence may be found at the beginning of the paragraph, in the middle or at the end. Thus, it is the central idea that is developed in a paragraph.

\subsection{The Properties of a Good Composition:}

A good composition should have the following properties: coherence, unity and order of importance.

\section{3. 1. Coherence:}

It is an application of the general use of this term in discourse analysis, referring to the main principle of organization postulated to account for the underlying functional connectedness or identity of a piece of spoken or written language (Text, discourse). It involves the study of such factors as the language users' knowledge of the world, the inference they make, and the assumptions they hold, and in particular of the way in which coherent communication is meditated through the use of speech acts. In this context, coherence is usually contrasted with cohesion, which refers to the syntactic or semantic connectivity of linguistic forms at a surface-structure level of analysis, Crystal (2003: 81). No doubt that coherence makes writing smoother and polished. Scholars (Suberman, 1956: 172, Glatthorn \& Rosen, 1990: 107; Al- 
Hamash, 2000: 29, Kies; 2008: 1, among many others) agree that a paragraph has coherence when sentences follow a logical order; that is, a paragraph has the quality of coherence when all parts cling together in a systematic arrangement. Coherence, therefore, is the product of many different factors, which combine to every paragraph, every sentence and every phrase contribute to the meaning of the whole piece.

\section{3. 2. Unity:}

Linguists do not talk about the unity of composition but they usually give some properties of a unified paragraph. To achieve a paragraph unity, a writer must ensure two things: First, the paragraph must have a single generalization that serves as the focus of attention, i.e., a topic sentence. Second, a writer must control the content of every other sentence in the paragraph's body such as: (a) more specific information than the topic sentence and: (b) maintaining the same focus of attention as the topic sentence (Kies, 2008: 1). In this regard, Glatthorn and Rosen (1990: 107) point out that a paragraph has unity when all the sentences tell about one main idea. In the same vein, Al-Hamash (2000: 26) states that a paragraph has unity when each sentence is clearly related to the controlling idea and when no important information about the controlling idea is missing. Lack of unity stems when the writer mistakenly includes one or two sentences that do not belong (Glatthorn and Rosen, Ibid).

\section{3. 3. Order of Importance:}

The order of importance is the way of organizing ideas according to the degree of their value, power, authority, interest, or quality (Marques, 2008: 1 \& 110). Glatthorn and Rosen (1990: 110) state that if you use order of importance to recognize a paragraph, you can begin with the most important details and end with least important details. They add that you can also begin with least important and end with the most important ones. 


\section{4. Punctuation and Mechanics of Writing Composition:}

Punctuation marks are signs or symbols that string all the words together and they make the meaning clear (Al-Hamash, 2000: 43). They act as signals to readers and tell them where to pause or stop (Forlini, 1982: 333 and Furnish, 1996: 85) when to read with a questioning tone and when to read with excitement (Forlini, 1982: 333). They also connect ideas or set ideas apart.

In this research, we are concerned with the use of "semicolon". A semicolon looks like a full stop (period) above a comma (;) (Forlini, 1982: 333). They are used to join two sentence structures that are connected by conjunctive adverbs or phrases like besides, however, indeed.....etc. (Furnish, 1996: $89 \mathrm{f}$ ). They are considered as longer pauses than is indicated by commas. They are also used when one wants the reader to see that the thoughts contained in two independent clauses are closely related. They can also show that a number of short sentences are linked in meaning (Al-Hamash, 2000: 49 f). For example:

I walked up behind Ali as quickly as I could; however, he still heard me.

It is important to mention that semicolons used to separate independent clauses such as: but, as you will, also recall, and finally. They also show how to place the two thoughts in the same sentence (Suberman, 1956: $38 \mathrm{f}$ ). Thus, punctuation marks are signs or symbols that string all the words together and they make the meaning clear like semicolon.

\section{Procedure and Data Analysis:}

This paper selects (26) compositions written by first year students in the college of Physical Education. Many steps are followed in order to enable the students to write these explanations. The first is to give them an explanation of the subjects to be tackled in writing a descriptive composition. The second step is to explain briefly the basic steps of writing, the division of idea into controlling and minor ideas, the 
arrangement of information, expressing thoughts in English, the division of composition paragraphs, and finally ending the composition adequately. In writing, the students depend on their background knowledge in English, as well as on the information given by the researchers. Moreover, the researchers have given them information about writing a good composition, including, mechanics of writing and arranging ideas cohesively. The researchers have also explained to them, how to end their composition successfully. The topics that the students are asked to write on are. " your friend", "your home", "rainy day", or "your first day in college". Most of the instructions and subjects were taken from (Al-Hassan and Razzak, 2000: 7778 - 91 - 92).

The researchers followed Searle and Dillon method of analyzing data, so the criteria for good writing could be classified in three major categories; mechanics (legible handwriting; correct spelling and punctuation, etc), language structure (correct sentence structures, proper use of tense, good use of topic sentence, and good paragraph construction, etc). and style (interesting style, good variety of sentences, different ideas divided in to different paragraphs, imaginative and precise use of vocabulary, good organization, use of connectives, individual style, etc). All three categories deal with forms of language (Searle and Dillon, 1980: 238) as shown in the following table.

\begin{tabular}{|c|c|c|c|c|c|}
\hline & $\begin{array}{c}\text { Mechanics of } \\
\text { Writing }\end{array}$ & $\begin{array}{c}\text { Language } \\
\text { Structure }\end{array}$ & Style & $\begin{array}{c}\text { No. of } \\
\text { Errors }\end{array}$ & $\%$ \\
\hline Introduction & $(40) 24,6 \%$ & $(38) 32,4 \%$ & $(34) 30,9 \%$ & $(112)$ & $28,7 \%$ \\
\hline Body & $(89) 54,9 \%$ & $(50) 42,7 \%$ & $(46) 41,8 \%$ & $(185)$ & $47,5 \%$ \\
\hline Conclusion & $(33) 20,3 \%$ & $(29) 24,7 \%$ & (30) $27,2 \%$ & $(92)$ & $23,6 \%$ \\
\hline Total & (162) $41,6 \%$ & $(117) 30 \%$ & (110) $28,2 \%$ & 389 & \\
\hline
\end{tabular}

The errors in mechanics of writing, language, structure, and style are found in all composition paragraphs, the rate of errors in body takes the 
highest proportion. It is about $(47,5 \%)$ as shown in the table above. The second high proportion of errors is found in the introduction. It is about $(28,7 \%)$. The third rate is found in the conclusion which is the lowest proportion. It is about $(23,6 \%)$.

Below are the tables of statistical results of the tests:

Table (1): First category (Mechanics of writing)

\begin{tabular}{|c|l|c|c|}
\hline $\begin{array}{c}\text { Types of } \\
\text { Errors }\end{array}$ & \multicolumn{1}{c|}{ Examples } & $\begin{array}{c}\text { No. of } \\
\text { Errors } \\
\text { Frequency }\end{array}$ & $\%$ \\
\hline Spelling & $\begin{array}{l}\text { * happe } \\
\text { - happy }\end{array}$ & 100 & $61,7 \%$ \\
\hline Punctuation & $\begin{array}{l}\text { * I like my friend, He tall and thin, He play } \\
\text { the teens. } \\
- \text { I like my friend. He is tall and thin. He } \\
\text { plays tennis. }\end{array}$ & 62 & $38,2 \%$ \\
\hline Total & & 162 & $41,6 \%$ \\
\hline
\end{tabular}

Table (2): Second Category (language structure)

\begin{tabular}{|c|c|c|c|}
\hline $\begin{array}{c}\text { Types of } \\
\text { Errors }\end{array}$ & Examples & $\begin{array}{c}\text { No. of } \\
\text { Errors } \\
\text { Frequency }\end{array}$ & $\%$ \\
\hline $\begin{array}{l}\text { Sentence } \\
\text { Structure }\end{array}$ & $\begin{array}{l}\text { * In the one day when He was work in the } \\
\text { streat in the Sadenley rainning say in the my } \\
\text { head. } \\
\text { - One day, when he was working on the } \\
\text { street, suddenly it rained on his head. }\end{array}$ & 34 & $29 \%$ \\
\hline Tense & $\begin{array}{l}* \mathrm{He} \text { is strong, He loved contry. } \\
-\mathrm{He} \text { is strong. He loves his country. }\end{array}$ & 50 & $42,7 \%$ \\
\hline $\begin{array}{c}\text { Topic } \\
\text { Sentence }\end{array}$ & $\begin{array}{l}\text { * In a first day in the college, I was very } \\
\text { happy becuse, I come to college } \\
\text { - My first day at college was a very } \\
\text { wonderful day because I transferred from } \\
\text { secondary school to the college. }\end{array}$ & 18 & $15,3 \%$ \\
\hline & & & \\
\hline
\end{tabular}

Table (3): Third Category (Style)

\begin{tabular}{|c|c|c|c|}
\hline $\begin{array}{c}\text { Types of } \\
\text { Errors }\end{array}$ & Examples & $\begin{array}{c}\text { No. of } \\
\text { Errors } \\
\text { Frequency }\end{array}$ & $\%$ \\
\hline Ideas & $\begin{array}{l}\text { * And the rain make the weather nice so it } \\
\text { good for animals because Animals drink }\end{array}$ & 47 & $42,7 \%$ \\
\hline
\end{tabular}




\begin{tabular}{|c|c|c|c|}
\hline & $\begin{array}{l}\text { from the rain water. } \\
\text { - The rain has many benefits for both } \\
\text { human beings and animals. First, it makes } \\
\text { the grass grow. Second, it makes the } \\
\text { weather very nice and covers the earth with } \\
\text { beautiful nature. }\end{array}$ & & \\
\hline Vocabulary & $\begin{array}{l}* \text { The Theaching of college is very } \\
\text { beutyful and generuse for people. } \\
\text { - Teaching in the college is very important } \\
\text { and useful for the students. }\end{array}$ & 26 & $23,6 \%$ \\
\hline Organization & $\begin{array}{l}\text { * My friend, I like my friend He is help } \\
\text { me and I am help his name is Aows. } \\
\text { - I like my friend; he likes me too. We help } \\
\text { each other. My friend's name is Aows. }\end{array}$ & 37 & $33,6 \%$ \\
\hline Total & & 110 & $28,2 \%$ \\
\hline
\end{tabular}

Table (4): The Overall Number of Errors and their Percentage of their Whole Categories

\begin{tabular}{|c|c|c|}
\hline Types of Errors & No. of Errors & $\%$ \\
\hline Mechanics of Writing & 162 & $41,6 \%$ \\
\hline Sentence Structure & 117 & $30 \%$ \\
\hline Style & 110 & $28,2 \%$ \\
\hline Grand Total & 389 & \\
\hline
\end{tabular}

\section{Results and Discussion:}

Though the students were given lectures about writing composition, they found serious difficulties in writing a descriptive composition. The researchers found from analyzing the test that (13) compositions were rather good and the other (13) were not adequate. The good compositions were characterized by right use of mechanics of writing, good ideas, arrangement of good information according to the rules of composition writing and organizing the sentences in paragraphs 
cohesively. However, some week points have been identified in their writings. First, the interference of the mother tongue, spelling mistakes and grammatical mistakes. The other (13) compositions were full of grammatical and spelling mistakes that constitute the highest in the total performance of the students; they lack arrangement of ideas, clarity and cohesion, as it is shown in the tables. So, the analysis of the compositions indicates that the large number of the students' errors $(41,6 \%)$ are in the mechanics of writing as shown in table (1). The language structure errors percentage was (30\%) as shown in table (2), whereas the stylistic errors percentage was $(28,2 \%)$ as shown in table (3) which is the lowest proportion. Generally speaking, it is also considered as a high rate of committing errors. This means that the students construct wrong sentences. Such errors seem to be due to the interference of the students mother tongue which is Arabic. The students tried to construct their sentences on the model of the Arabic structure which affects the style when writing in English.

\section{Conclusions:}

This paper proves that the $1^{\text {st }}$ year students of Physical Education College made all types of errors in composition writing. This investigation reveals that the high rate of errors in mechanics of writing which include spelling and punctuation is about $(61,7 \%)$. Whereas the second category is language structure errors, which includes sentence structure, tense, topic sentence. This has the highest rate of errors in the use of proper tense it is about $(42,7 \%)$. On the other hand, the stylistic errors, in the third category include ideas, vocabulary, and organization. The ideas constituted again a highly rate of $(42,6 \%)$. Here the reader may be confused, and also unable to understand what the student mean in his writing. 
Finally, the present study paves the way for adopting certain teaching programs and procedures intended for making the students think in English and express their ideas in correct sentences without interference with their mother tongue.

\section{REFERENCES}

1. Alexander, L. G. (1956). Essay and Letter Writing. England: Longman Group Ltd.

2. Al-Hamash, K. (2000). College Composition. Baghdad: the Institute for the Development of English Language Teaching.

3. Al-Nakkash, N. M. (1978). Different Techniques for Guided Composition. In Idelti; No. 10: p: 130 - 139.

4. Crystal, David (1980, 1985, 1991, 1997, 2003). A dictionary of Linguistics and Phonetics. Fifth Edition, Blackwell Publishing.

5. Chaplen, F. (1970). Paragraph Writing. London: Oxford University Press.

6. Forlini, G. , Bauer, M.B. , Biner, L. , Capo, L. , Kenyon, K. M. , Shaw, D. , and Verner, Z. (1982). Grammar and Composition. USA: Prentice-Hall.

7. Furnish, B. (1996). Write Right and English Book. Bloomington: PHI Delta: Kappa Press.

8. Glatthorn, A. A. and Rosen, B. C. (1996). English. USA: Mc Dougal, Little and Company.

9. Hanks, P. and Porter, S. (1971). Encyclopedia World Dictionary. London: Hamlyn Publishing Group Limited.

10. Hornby, A. S. Gatenby, E. V. and Wakefield, H. (1963). The Advanced Learner's Dictionary of Current English. 2nd. London: Oxford University.

11. Kies, D. (2008). The Hyper Text Books. Via Internet. 
12. Razzak, F. A. (2000). College Composition. Baghdad. Revised Edition.

13. Rutherford, R. (2008). Wikipedia Encyclopedia. USA.

14. Searle, D. and Dillon, D. (1980). "The Message of Marking: Teacher Written Responses to Student Writing at Intermediate Grade Levels". Research in the Teaching of English. Vol. 14, No. 3, October 1980.

15. Steel, M. (2000). Oxford World Power Dictionary for Learners of English. London: Oxford University Press.

16. Suberman, J. and Rosen Bury, H. M. (1956). Basic Composition. USA: Prentice-Hall.

17. Suleimani, H. (2004). Foreign Language Teaching Methodology Test. $2^{\text {nd }}$. Iran: Azad University. 


\section{APPENDIX}

\section{Test subject (1)}

\section{"Describe your friend"}

My friend, I have many friends but some friend was bad when I testing them.

I like my friend, He tall and thin , He play the teens.

the good friend helping his friend when he needes.

\section{Test subject (2)}

\section{Write a composition about:}

\section{1. my first day at college.}

My first day at college it was very very happiy. I love my college becuse it is my fivurit. I love my friend in college becuse I feel very happe with him. I love my techer in my college becuse very buttefull I come to college becuse I love all sports. I love play foot ball. I can take good marks in my work becuse I seen very eage. I wieh in butter grow techer on my college. I seen difernt betwn my college primary. I studed hard in my primary becuse go to universty.

\section{Test subject (3)}

\section{"Describe your Friend".}

I like to speak about this topic because it's very nice. I have a lot oF friends but I have one best Friend. I lived with him since smoll boy and until Now. he is my best Friend, I want describe him, he is tall and Not 
fat, and have nice Face, and he love to helped topeople and do For them anything as soon as possible. He love sporst and play volleyball. He was lived in my place street but aFter little period he leaved my place street and then and he transport to other town. In that time I had been very sad. But until Now I'm still with him, I visited him and he too. He studying Now and, I wish For him succeed in his exam. I'm waiting him to come here in university.

\section{Test subject (4)}

\section{Q1- write a composition about:}

\section{1- my first day at college}

\section{2- A rainy day}

\section{3- A spring season}

1- my first day at college

I intruduced to my friend in my college in the first stage and in new places when I came her I see a new teachers I visite all place in my college and all college around my college in the first day I was shying from my fraind cose I have the first day I met thim but now I very Glad in my college and with my fraind. 